\title{
Resource Use and Economic Impacts in the Transition from Small Confinement to Pasture-Based Dairies
}

\author{
Melissa Rojas-Downing ${ }^{\mathrm{a}}$, Timothy Harrigan ${ }^{\mathrm{a}^{*}}$, A. Pouyan Nejadhashemi ${ }^{\mathrm{a}}$ \\ a. Department of Biosystems \& Agricultural Engineering, Michigan State University, 524 S. \\ Shaw Lane, Room 206, East Lansing, MI 48824, U.S.A. \\ *Corresponding Author: Tel: +1 (517) 353-0767. Email address: harriga1@anr.msu.edu
}

\begin{abstract}
In recent years, many livestock farms have transitioned from total confinement housing to a pasture-based system in an effort to reduce labor and production costs and improve profitability. There is a growing interest in biogas recovery among livestock producers to reduce energy costs and manure odors but the economic benefits of anaerobic digestion (AD) on small farms is not well known. A comprehensive analysis was conducted using the Integrated Farm System Model (IFSM), to describe, evaluate and compare the farm performance and economic impacts of representative dairy farms in Michigan transitioning from conventional confinement to seasonaland pasture-based systems, and evaluate the potential for integration of an AD in the confinement and seasonal pasture systems. The results in farm performance present higher milk production per kilogram of feed in the confinement systems, followed by the seasonal pasture and the annual pasture systems. In the economic analysis, the annual pasture-based system had the greatest net return to management and unpaid factors followed by the seasonal pasture and confinement systems. The addition of an AD on a 100-cow, total confinement dairy decreased the net return to management and unpaid factors by $20 \%$. When anaerobic digestion was added to the seasonal pasture with an increased land base for cash crop production and an imported manure volume equivalent to a 500-cow dairy, the net return to management and unpaid factors increased $269 \%$ compared to the seasonal pasture dairy alone.
\end{abstract}

Keywords: Whole-farm Simulation, Dairy, Confinement, Pasture, Economic, Anaerobic digester 


\section{Introduction}

The United States has 9.3 million milking cows (USDA, 2016) and is the second largest milk producer in the world (FAO, 2016). The U.S dairy industry is concentrated in the Great Lakes region with $41 \%$ of the United States milking cows in 2015 (USDA, 2014). This region is well suited for dairying because forage is abundant and can be stored as winter feed (EPA, 2015). The Great Lakes region includes five of the top 10 milk-producing states in 2012: Wisconsin, New York, Pennsylvania, Minnesota, and Michigan (USDA, 2014). The Michigan dairy industry by itself contributes $\$ 14.7$ billion to the state economy (UDIM, 2016).

Dairy farming has different production systems including confinement, seasonal pasture, and pasture-based. A confinement dairy is a system where land use and feed management systems optimize milk production with confined cows consuming harvested forages and concentrates (Aschmann and Cropper, 2007). Almost all the herd is housed in a free stall or structure system with no access to pasture (Powell et al., 2005). In a seasonal pasture system, cattle are on pasture during the summer growing season and confined during winter. A pasture-based dairy uses land use and feed management systems that optimizes the intake of forages consumed directly by grazing cows. In this system, during the grazing season, the lactating animals will consume at least $50 \%$ of their forage intake through grazing, while dry cows consume $90 \%$ (Aschmann and Cropper, 2007). Forage is defined as edible portions of plants (commonly excluded grain) that can be grazed or harvested by animals (Wilkins, 2000). Pasture refers to the interactions between soil, plant and grazer used in a management unit devoted to produce forage for grazing animals (Rayburn, 2007).

In recent decades, many U.S. dairy farms have increased their net income by expanding herd size (Nott, 2003; Aschmann and Cropper, 2007). This increased the demand for feed and forage and encouraged the use of confinement systems. Large confined herds required larger structures for housing and feed storage and larger handling equipment and waste management systems (Aschmann and Cropper, 2007). However, a transition from confinement dairy to pasture-based dairy has been adopted due to the profitability in the dairy industry in the Great Lakes Region (Nott, 2003). Pasture-based dairies can reduce feed, labor, equipment and fuel costs. It provides a lower-cost option for small farmers without expanding their dairy farm, or they can start dairying with less debt (Aschmann and Cropper, 2007). Economic studies show that grazing farms can 
provide satisfactory profits compared with confinement operations. Pasture-based systems generated $\$ 887$ net farm income from operations (NFIFO) per cow and $\$ 4.22$ per hundredweight equivalent (CWT EQ), compared to confinement operations, which generated $\$ 640$ NFIFO per cow and a negative $\$ 10$ per CWT EQ (Kriegl and McNair, 2005).

In the transition from a confinement to pasture-based dairy, it is important to consider all aspects of production and operation. Some changes needed to increase efficiency are to improve the milking facilities to reduce milking time; improve pasture fertilization by soil testing and applying recommended fertilizer rates; and reduce expensive farm machinery investments. In addition, during the grazing season the efficiency can increase by feeding pasture forage based on cattle dry matter intake, amount of standing forage within the paddock, and on forage nutrients (Aschmann and Cropper, 2007). During the transition from confinement to pasture system, there will be a temporary loss of milk production (Kriegl and McNair, 2005) because cows that have never grazed before expect feed that is provided in the barn. However, milk production will increase and meet or exceed their level of production when the cows have improved their grazing and maximize dry matter intake from pasture (Heckman et al., 2007).

One of the main global issues of livestock production is manure management (Teenstra, 2014). In 2007, there were 9,158 milking cows on 71,510 operations in the U.S. (Betts and Ling, 2009). These cows produced 84.2 billion kilograms of milk along with an estimated 226.8 billion kilograms of manure (Betts and Ling, 2009). Manure processing is routinely handled by collecting, storing and spreading it over the land. However, manure management practices has generated environmental concerns such as odor, water quality, and greenhouse gas emissions. Global livestock production contributes with $14.5 \%$ of greenhouse gas emissions, where only manure management contributes with $26 \%$ of the sector emissions (Gerber et al., 2013). Livestock manure releases methane and nitrous oxide gasses. The organic materials decomposition found in manure under anaerobic conditions releases methane (EPA, 1999). Manure handled aerobically and then anaerobically releases nitrous oxide, which usually occurs during manure storage and application (Steinfeld et al., 2006). The environmental concerns, in addition to the increase in energy costs and growing interest in renewable energy has encouraged farmers to search for alternative manure handling methods (Hadrich and Wolf, 2011; Betts and Ling, 2009). 
One of the alternatives that produce renewable energy in cost-effective ways is biogas recovery (USDA et al., 2014). The use of this technology has been increasingly attractive for manure management with around 30 million anaerobic digesters operating worldwide with manure (Chen et al., 2010). EPA estimated that there were 188 anaerobic digesters operating at commercial livestock farms for biogas recovery in the United States in 2012, and 158 were dairy digester projects (EPA, 2013). Anaerobic digestion (AD) is a process where anaerobic bacteria degrade organic materials in an oxygen free environment to create biogas (mix of methane and carbon dioxide), which can be used to produce electricity and heat (Burke, 2001). This process has been successful in developed and developing countries over many years because of the potential for global energy needs and multiple environmental benefits. For example, in 2008, about 4,000 anaerobic digesters in Germany were operated in the agricultural sector to produce biogas (Weiland, 2010). In Europe, the policy states that $25 \%$ of all bioenergy can at least be derived from biogas (Holm-Nielsen et al., 2009). In China, about eight million AD are used to produce biogas for cooking and lighting in households (IEA Bioenergy, 2005). In the world, more than thousand vendor-supplied AD are operating or under construction, with the majority located in South America to treat the vinasse coproduct from sugar cane-based ethanol production (Lettinga and Haandel, 1992).

The input for an anaerobic digester is biomass, such as manure, agricultural waste, and urban waste, though they are not similarly degraded or converted to gas (Burke, 2001). The use of animal manure as biomass for AD is globally widespread because it produces a valuable fertilizer (or also known as digestate) as well as biogas (IEA Bioenergy, 2006). For example, a typical lactating dairy cow can support the production of 1.33 cubic meters of biogas per day (Betts and Ling, 2009). Assuming that the biogas contains 65 percent methane, this would mean $0.62 \mathrm{~kg}$ of methane per cow per day. The U.S. Environmental Protection Agency (EPA) in 2010 estimated 8,200 U.S. dairy and swine operations produce more than 13 million MWh of electricity with biogas recovery systems; where only dairy produces about 6.8 million MWh.

Besides producing electricity, biogas recovery systems on livestock operations can also heat water and provide additional benefits to the farm (EPA, 2010). The digestate, which is the non-gaseous material remaining after digestion, can be used as a fertilizer and bedding and can be often recovered for reuse (USDOE, 1996). Revenue from electricity generated on-farm can be 
obtained through biogas and electricity sale, reduction in purchased electricity use, and in some cases, net metering (Roos et al., 2004). AD also has an environmental impact by reducing greenhouse gas emissions and odors (IEA Bioenergy, 2006). From each ton of carbon recycled, revenue may be obtained through carbon credits if methane is captured and prevented from escaping to the atmosphere.

Anaerobic digestion also impacts farm economics. In the case of small-scale digesters, U.S. EPA does not recommend biogas recovery systems for livestock farms with less than 500 cows (EPA, 2010). In 2010, the majority (74\%) of U.S. dairy farms had less than 100 cows and in 2011, 88\% had less than 200 cows, making anaerobic digestion not feasible for most of U.S. dairy farms (U.S. Census Bureau, 2012). For example, revenue from electricity sales has been profitable for large-scale operations (Nelson and Lamb, 2002), but small-scale digesters are not often profitable due to their dependence on the electricity price and the high cost of infrastructure needed to sell electricity back to the grid (Lazarus and Rudstrom, 2007; Ghafoori and Flynn, 2007). Electrical generation from biogas was not economically viable but the use of biogas to accomplish the heating requirements on-farm was found to be economically feasible in smallscale dairy farms (Bishop and Shumway, 2009). However, Millen (2008) reported on two small dairy farms (130 and 70 cows) in Ontario that were producing electricity and were profitable. The farmers credited their success to receiving three tons per day of additional waste such as grease trap waste (130 cow farm only), having a buyer for their electricity, and substantial time dedicated to the project development stage.

The Minnesota Project, a group funded by EPA-AgSTAR, is searching for solutions for small- and mid-sized dairies. In 2005, they started a feasibility study on the use of the anaerobic digestion technology by scaling it down and still providing financial incentives for farmers to use it. The Minnesota Project evaluated six anaerobic digestion systems designed for confinement dairies between 100 and 300 cows. They concluded that the digester costs, which were between $\$ 105,000$ and \$230,000, were still too high (Goodrich, 2005).

The Minnesota Project prepared a case study based on the Jer-Lindy confinement dairy farm in central Minnesota. This farm has 97 ha and 160 milking cows producing about 11,356 L per day of manure based on built a small-scale digester with an up-flow tank system with a 124,918 L holding capacity and five-day hydraulic retention time (HRT). The total cost of the 
system was $\$ 460,000$ (Lazarus, 2009). The economic analysis evaluated the added value by the generator and the projected costs of owning and operating it. The analysis assumed that the system would produce $430 \mathrm{kWh}$ of electricity per day in which $95 \mathrm{kWh}$ was used to run the pumps, digester and fan separation equipment and $335 \mathrm{kWh}$ per day to replace electricity purchases or to sell back to the grid. The manure solids from the separator replaced the sand bedding that normally costs around $\$ 1,000$ per month (Lazarus, 2009). Solids breakdown in the digester was assumed to reduce manure hauling and agitation costs by $\$ 2,400$ per year. The most liquid fraction of the digestate could be applied at higher rates on less areas and possibly reduce the pumping cost. The sale of carbon credits due to the breakdown of methane in the anaerobic digestion process was considered as an additional source of income (Lazarus, 2009).

Perhaps the greatest operational challenge in integrating anaerobic digestion and in small scale dairy farms and pasture-based dairies is the variable and seasonal supply of feedstock. There is also a need for further research to make anaerobic digestion byproducts more readily available, cost effective, and manageable to small dairy facilities in the United States. However, considering all of the above factors while performing large-scale analysis is complex and requires computer models.

Researchers have created computer models that simulate crop growth, environment and farming systems, such as integrated crop/livestock systems. Computer models allow the analyst to predict the effect of changes in complex systems (Maria, 1997). Models can help stakeholders understand potential benefits, tradeoffs, costs and impacts associated with management, environmental and other factors (Loucks and Beek, 2005).

Livestock and cropping systems models are often constrained by geographic location or cropping options. The DairyWise dairy farm model simulates popular feed crops like grazed grasses or corn (Sendich, 2008). The Dairy Greenhouse Gas Abatement Calculator (DGAS) is designed for the Australian climate and is not applicable for the Great Lakes Region (The University of Tasmania, 2013).

Whole farm simulation models such as the Integrated Farm System Model (IFSM) and IFARM, which integrates crop and animal management components, are useful models that can be used either for crop/livestock systems, crop systems or livestock systems (Sendich, 2008). Iowa State University created a whole-farm simulation model called I-FARM, which predicts 
economic and ecosystem impacts due to farm operations across the United States. The model includes several crops and crop rotations with associated tillage, fertilization, planting, weed control, harvesting, and residue removal. Livestock systems are simulated based on feed intake, growth rate, grazing or confinement options, and manure management systems (Iowa State University, 2010). One of the main differences between I-FARM and IFSM is that IFSM integrates anaerobic digestion as a waste management system, which is uncommon for whole farm simulation models.

IFSM uses historic weather data to determine long-term farm performance, environmental, and economic impacts of dairy operations. The simulation includes all of the major processes involved in the farming system including crop establishment, crop production, harvest, storage, feeding, milk production, manure handling and the return of manure nutrients back to the land (Rotz et al, 2011). Recently, a sub-model was added to include on-farm anaerobic digestion.

IFSM has been used to compare pasture-based with confinement system dairies. Rotz et al. (2009) used IFSM to compare the predicted environmental impacts of four different dairy operations in a 101 ha dairy farm typical in Pennsylvania, where two of them were confinement dairies and two were rotational grazing systems. However, there is a lack of information for evaluating the transition from a confinement system to a pasture-based system and the feasibility of anaerobic digestion in such systems.

Rotz and Hafner (2011) evaluated the environmental and economic impact of the addition of an $\mathrm{AD}$ on a New York state large confinement dairy farm (1,100 cows) over 25 years of weather. They used farm records to validate simulated feed production and use, milk production, biogas production, and electric generation and use. The digester reduced the net greenhouse gas emissions and farm gate carbon footprint by 25 to $30 \%$. However, there was no direct farm profit that could benefit the producer. There is a need to evaluate the resource use and economic impact of the integration of an $\mathrm{AD}$ on a seasonal pasture-based system dairy farm with fewer than 500 cows.

In this current study, we conducted an analysis using IFSM to describe, evaluate, and compare the economics and resource of representative dairy farms transitioning from conventional confinement to a year round pasture-based system and the potential for integration of an $\mathrm{AD}$ in a small confinement and seasonal pasture dairy farm. For this study, transition refers 
to a potential step-wise progression and comparison of a conventional confinement to a seasonal pasture-based to a year round pasture-based system. Each system is considered to be an independent strategic management option rather than a continuous dynamic process. The specific objectives of this current study were to:

1) evaluate the operating costs and labor requirements of representative confinement-based and seasonal-and pasture-based systems, including all major interactions from harvest and feeding through manure application, tillage and planting, and

2) compare the economics and performance of an $\mathrm{AD}$ on representative confinement and seasonal pasture dairies.

\section{Methods}

In order to describe, evaluate and compare dairy farms representing a conventional confinement, seasonal pasture-based, year round pasture-based system and the potential for integration of an $\mathrm{AD}$ in the confinement and seasonal pasture dairy farm, five representative dairy farms were developed using the IFSM model. The representative farms do not describe a specific farm; rather they are designed to reflect common features regarding land base, machine selection, crop production, number of cows and young stock and other key components. The five systems include: 1) conventional confinement system with 100 large-frame Holsteins, 2) conventional confinement system with 100 large-frame Holsteins and an AD, 3) seasonal pasture system with 142 medium-frame Holsteins, 4) seasonal pasture system with 142 medium-frame Holsteins, an expanded land base for cash crop production with imported manure and an AD and, 5) annual pasture-based system with 160 small-frame New Zealand Friesian cows. Therefore, the independent strategic management options will be evaluated by comparing the IFSM output of the three fixed systems representing a confinement, seasonal pasture and pasturebased farm. The potential for integration of an AD will be evaluated by comparing the IFSM output of the four fixed systems representing a confinement and seasonal pasture farm with and without AD. The analysis was conducted over 26 years of Lansing, Michigan weather conditions to obtain a comprehensive analysis of system performance. The different farms were compared by observing the outputs of farm performance. Farm performance included economics and resource use, annual production costs and net return to management; crop production costs and 
total feed costs. A calculation of the difference between annual means of each farm was compared.

\subsection{Representative farm development}

Five representative farms were simulated based on information collected from farm visits, literature review, and discussions with dairy extension professionals across the Lower Peninsula of Michigan. The collected information can be found in Rojas-Downing (2013). These representative farms were selected to provide a near balance between the land base and feed produced, and a nutrient balance between the manure nutrients applied and imported in purchased feed, and the nutrients used for crop production, exported milk, or otherwise exported from the farm. Whole-farm nutrient balances are key for understanding and evaluating the profitability of a dairy farm and for minimizing the nutrient related environmental risk (Koelsch and Lesoing, 1999; Castillo, 2009). The nutrient balance in this study is used to maintain soil fertility with small amount of soil phosphorus and potassium build-up or depletion.

Nutrient balance on farm can vary depending on the dairy system. Confinement operations have more control of feed quantity and nutrient concentration during the year, which helps to stabilize milk production and nutrient concentrations in manure (Wattiaux and Karg, 2004). Confinement farms tend to import more nutrients than needed by the crops, and nutrient imbalance can result mainly when manure is applied in addition to fertilizer applications in the absence of a regular soil testing program (Aschmann and Cropper, 2007). In a pasture-based system, seventy to eighty percent of nutrients of consumed feed and forage is returned to land (Whitehead, 1995). The dairy cattle diet, such as supplemental forages and concentrates, needs to maintain a balance of nutrients going out through milk production to reduce fertilizer applications. This maintains fertility levels in the cropland by replacing, with manure or inorganic fertilizer, the nutrients that leave the field in the harvested crop. Between 70 and 90 percent of the phosphorus, potassium, calcium and magnesium consumed by dairy cattle are excreted back onto the pasture (Mott, 1974). However, when livestock production is integrated with crop production the sustainability of the agricultural system is improved by using waste products of one component as a resource for the other (Rota and Sperandini, 2010; Sulc and Franzluebbers, 2014). The greater biodiversity in integrated crop/livestock systems results in an 
improvement of the nutrient cycling on-farm, such as applying manure back to the land where the animals consumed the feed (Russelle et al., 2007). By diversifying products and improving soil fertility some benefits might occur such as the decrease of production costs, the increase of yields, the income source is more diversified and the profit might rise (Rota and Sperandini, 2010; Russelle and Franzluebbers, 2007).

Based on farm visits and discussions with dairy farmers considering the transition from total confinement to an annual pasture-based system, a herd size of 100 cows is a common tipping point in the decision to continue with total confinement facilities and expand herd size or maintain herd size and begin the transition to a seasonal or annual pasture-based system to reduce operating costs. Therefore, the initial representative farm for analysis was a milking herd of 100 large-frame Holstein (726 kg mature weight) cows with 80 replacements in conventional confinement housing. Total confinement systems typically have large-frame Holsteins bred for high milk production. Ninety percent of U.S dairy cows are black and white Holsteins. Holsteins can produce large volumes of milk, butterfat and protein. When fed high levels of grain the cow can be very profitable (EPA, 2015). The land base of this system is 111 ha (275 ac, 1.11 ha $(2.75 \mathrm{ac})$ per cow). This land base balanced feed produced on the farm with small amounts of purchased or sold forage or grain, and balanced manure nutrient application with crop removal to maintain a near nutrient balance on the farm.

For seasonal pasture systems farmers typically prefer smaller cattle with traits and genetic potential for milk production between the large-frame and small-frame cows, such as mediumframe Holsteins. Smaller frame cattle generally consume less feed and produce less manure than large-frame cattle. Therefore, a seasonal pasture system with 142 medium-frame Holstein cows (590 kg mature weight) with the same land base as the confinement system (111 ha) was evaluated as the representative seasonal pasture farm. The land base was held constant and the cow numbers were increased to maintain the balance between land available for feed production and the nutrient balance on the farm with only small amounts of forage purchased or sold.

In an annual pasture-based system, New Zealand Friesian cows (454 kg mature weight) are typical (similar to a small-frame Holstein) because of their efficient conversion of grass to milk. Cattle are supplemented with some dry hay, round bale silage and a small amount of purchased grain with minimal housing throughout the year. The representative annual pasture- 
based system had 160 New Zealand Friesian cows with replacements on the 111 ha land base. These cow numbers and land base provided a near balance of feed produced and nutrient use on the farm.

\subsubsection{Type of Manure Treatment}

Two types of manure treatment were evaluated: land application of raw manure and anaerobic digestion. Land application of raw manure means that all manure collected on-farm was applied to the cropland. When an AD was used, all the manure collected and/or imported was used as biomass for the digester and the digestate from the digester was applied to cropland.

Three of the five representative farms were evaluated with a land application of manure. Those farms are the 1) conventional confinement system with 100 large-frame Holsteins, 2) seasonal pasture system with 142 medium-frame Holsteins, and 3) annual pasture-based system with 160 small-frame New Zealand Friesian cows. The remaining two representative farms were evaluated with the integration of an $\mathrm{AD}$, which are the 1) conventional confinement system with 100 large-frame Holsteins and an $\mathrm{AD}$ and 2) seasonal pasture system with 142 medium-frame Holsteins, an expanded land base for cash crop production with imported manure and an AD (Figure 1). The last two representative farms with AD were developed to evaluate the economic feasibility and performance of small farms with AD. For the confinement farm, the feasibility of a limited herd number (i.e. 100 cows) was evaluated, while for the seasonal farm the feasibility was tested by importing enough manure to provide a steady supply for the AD.

Anaerobic digesters require a steady supply of manure throughout the year for efficient use. A herd size of 500 cows was considered the break-even point of investment for an AD, where the farmer was able to cover all expenses with income (EPA, 2010). One alternative for the cost effective integration of an $\mathrm{AD}$ on a small seasonal pasture dairy may be to import manure from nearby dairies, thereby providing a steady, year round supply of manure in a quantity that is economically feasible. However, we did not considered the existing social network between farmers for biomass flow since this was beyond the scope of this study. The economics and performance of the representative 142-cow seasonal pasture dairy was evaluated when importing 12,882 wet $\mathrm{t}$ of dairy manure from nearby dairies $(1.2 \mathrm{~km})$. This volume of manure, when added to the manure deposited in the barn by the milking herd (2,865 t/yr), provided an annual manure volume similar to that produced on a 500-cow dairy $(13,900 \mathrm{t} / \mathrm{yr})$. 
Therefore, the $\mathrm{AD}$ installed on the seasonal pasture dairy was sized to process 15,747 wet $\mathrm{t}$ of manure with 2,865 wet $t$ produced by the cattle at the facilities and 12,882 wet $t$ of manure imported from nearby farms. In addition, due to the imported manure, the seasonal pasture farm cropland was increased from 111 ha to 809 ha to balance the additional nutrients from the imported manure with crop removal. Corn area was increased from 75 ha to 374 ha and 374 ha of soybeans were added as a cash crop.

IFSM is not currently designed to evaluate an AD with imported manure. Therefore, the performance and economics impact of the seasonal pasture dairy was approximated by integrating multiple representative farms: (1) 142-cows seasonal pasture dairy with AD, (2) 142cows seasonal pasture dairy with imported manure and an expanded land base for cash crop production and manure use, (3) 500-cows confinement dairy farm, and (4) 500-cows confinement dairy farm with $\mathrm{AD}$. In order to evaluate the integration of a seasonal pasture farm with an $\mathrm{AD}$ the differences and percentages calculated between: (1) the confinement farm with 500 cows with and without $\mathrm{AD}$, (2) the seasonal pasture farm with 142 cows with and without $\mathrm{AD}$, and (3) the seasonal pasture farm with 142 cows and the 142-cows seasonal pasture farm with imported manure and an expanded land base use were used (Appendix A.4 and A.5).

Because IFSM does not account for the separate labor and machinery requirements for imported manure in the seasonal pasture farm with $\mathrm{AD}$, the costs related to importing the additional manure and the land application of it were calculated, and these costs were added to the farm production costs (Appendix A.1). The cost of importing manure as fertilizer was calculated based on the amount of $\mathrm{N}, \mathrm{P}_{2} \mathrm{O}_{5}$, and $\mathrm{K}_{2} \mathrm{O}$ in the imported manure. The amount of $\mathrm{N}$ (3.8\% DM), $\mathrm{P}_{2} \mathrm{O}_{5}(0.8 \% \mathrm{DM})$, and $\mathrm{K}_{2} \mathrm{O}(2.4 \% \mathrm{DM})$ in the manure was obtained from the manure characteristics of ASABE D384.2 standard (ASABE, 2014). Each amount of $\mathrm{N}, \mathrm{P}_{2} \mathrm{O}_{5}$, and $\mathrm{K}_{2} \mathrm{O}$ contained in the 1,288.2 $\mathrm{tDM}$ of imported manure, was multiplied by the price of the commercial fertilizer ( $\$ 1.19 / \mathrm{kg} \mathrm{N}, \$ 1.63 / \mathrm{kg}$ P2O5, $\$ 1.26 / \mathrm{kg} \mathrm{K2O}$ ), assuming they are needed and fully utilized by the growing crops. Agitation, pumping and trucking manure from nearby farms to the $\mathrm{AD}$ was done on a custom hire basis at $\$ 90$ per hour assuming custom hauling with a 22,712 L (6,000 gallons) truck-mounted tank and a $1.6 \mathrm{~km}$ hauling distance with a hauling rate of $52,769 \mathrm{~L} / \mathrm{h}(13,940 \mathrm{gal} / \mathrm{h})$ for $15,747 \mathrm{t}$ of wet manure per year. Custom manure hauling 
required 301 hours per year. Machine efficiency and labor hours were calculated based on Harrigan (2010).

Hauling manure from the AD to the field required two 18,927 L (5,000 gallons) tank spreaders with $100 \mathrm{~kW}$ tractors with an average hauling distance of $1.2 \mathrm{~km}$. The average hauling rate was 53,942 L/h (14,250 gal/h) and required 148 hours for each tractor and spreader (296 h) based on Harrigan (2010). Labor for pumping and agitating manure required 42 machine hours for agitating and pumping, and 8 hours for agitating and clean-up each time the manure storage was emptied (assumed two times per year) (Appendix A.1). Machine efficiency and labor hours were also calculated based on Harrigan (2010). Repair factors, operating costs, salvage value and interest rates were calculated based on Hadrich et al. (2010), ASABE standard D497.7 (2015b) and ASABE standard EP496.3 (2015a).

\section{Figure 1}

\subsubsection{Anaerobic digestion}

IFSM predicted the production and use of energy, and the effects that anaerobic digestion has on manure and economics. The AD manure loading rate was the amount of manure excreted and collected from barns or transported to the farm from off farm locations. Biogas is produced through the microbial degradation of the volatile solids in the manure. Energy production was based on the rate of volatile solids (VS) flow into the digester from animals. The amount of methane produced was a function of the productivity, which was set at $0.35 \mathrm{~kg} \mathrm{CH}_{4} / \mathrm{Kg} \mathrm{VS}$ (Moller et al, 2007), and a function of the conversion efficiency, which had typical values close to $35 \%$ (Burke, 2001; Rotz et al., 2011).

Producing power with biogas was a function of the energy content of methane, which also depended on biogas leakage (set as a typical value of 15\%) (Anaerobic Digestion Research and Education Center, Michigan State University, 2013). IFSM first predicted the amount used to heat water, which was set as $40 \%$ of the gas production, and the remaining was available to generate electricity (Table 1). The amount of electricity produced each day was limited by either the capacity of the generator, operation time and the amount of biogas. The efficiency of the engine-generator was set as 35\% (Anaerobic Digestion Research and Education Center, Michigan State University, 2013). Any remaining biogas that was not used for either on-farm electricity generation or water heating was burned off in a flare. By burning the biogas the lost 
carbon converted to carbon dioxide, which reduced the global warming potential of methane emission.

The initial costs for the AD were calculated using a model provided by Anaerobic Digestion Research and Education Center, Michigan State University (2013), where the cost of the digester was calculated based on $\$ 7,000 / \mathrm{kW}$ and the generator was assumed to be $50 \%$ of the cost of the digester. The digester cost was obtained from a review of like projects around the United States. The initial costs of the digester and generator included: digester structure, electrical generator, design, construction, planning and, digestate management. The model do not include modifications required to collect and hold manure prior to entering the digester. The costs may be higher because the electric generation equipment, which is smaller than usual, may be difficult to find.

The input parameters were: quantity of manure, moisture content, volatile solids, total solids, volatile solids conversion efficiency and run time efficiency (Table 1). The model outputs were: initial cost of digester and generator, repair and maintenance cost, electric generation equipment, gross energy from biomass, net energy from electricity including efficiency, transportation waste energy, energy for heating influent and to operate $\mathrm{AD}$, and heat production from generator. For IFSM only the initial costs of the digester and generator described above, repair and maintenance costs and, electric generation equipment calculated from the model provided by Anaerobic Digestion Research and Education Center, Michigan State University (2013) were used (Table 1).

Even though the literature suggests that 500 cows in a confinement dairy farm is considered a break-even point for integrating an AD (EPA, 2010), an analysis to find this breakeven point using IFSM and the representative confinement farm with 500 cows (Appendix A.3) was performed. The analysis involved using the information of the representative confinement farm with 500 cows as the base farm and changing: (1) the number of cows, (2) the land base depending on the number of cows, (3) the manure storage depending on the amount of manure produced, (4) the digester costs, and (5) the amount of bedding purchased when the farm has an AD. Nine different farms with and without AD were compared. The parameters for each of the nine different farms that where changed based on the representative confinement farm with 500 cows can be found in Appendix A.7. The first farm had 375 cows and the remaining eight farms 
had $400,425,450,475,500,525,550$, and 600 cows. A break-even point is when the farmer will be able to cover all expenses with the incomes from the farm production. Therefore, the capital cost of the AD per cow and the net return to management and unpaid factors per cow was calculated. The intersection between these two values will show the break-even point for a confinement dairy farm to integrate an AD.

Table 1

\subsection{Herd and crop information of representative farms}

The herds followed a year-around calving strategy with a $35 \%$ culling rate for the confinement system, $25 \%$ for the seasonal pasture system and $30 \%$ for the annual pasture system as a result of healthier lactating cows, with less stress, more natural diet and, improved reproductive performance (Benbrook, et al., 2010). Labor for milking and animal handling was $5.25 \mathrm{~min}$ per cow-day for the confinement system, based on three times per day milking schedule and, 3.0 min per cow-day for the seasonal and annual pasture systems, assuming 2 times milking per day and lower milk production (Pasture-based Dairy Research and Education Facility, Michigan State University, 2013).

Milk production is a function of genotype, management level, nutrition and environmental factors. Large-frame Holsteins in confinement typically have greater annual milk production than small-frame cattle on pasture. The confinement system with 100 large-frame Holsteins had a target annual (305 days) milk production without fat added in the ration of $10,886 \mathrm{~kg} / \mathrm{cow}-\mathrm{yr}$. The seasonal pasture system with 142 medium-frame Holstein cows had a target milk production of 9,071 kg/cow-yr. The annual pasture-based system had a target milk production of 7,252 kg/cow-yr. Potential milk fat content was $3.5 \%$ for the large-frame cows, $3.8 \%$ for the medium frame cows and $4.2 \%$ for the small-frame cows (Pasture-based Dairy Research and Education Facility, Michigan State University, 2013). At these production levels, forage quality was the primary constraint to milk production.

The feed ration was determined by a linear program embedded in IFSM and it was selected to provide a relatively high forage-to-grain ratio for seasonal and annual pasture farms and a low forage-to-grain ratio for confinement farms. In addition, a minimum of 5\% dry hay in cow rations was fed for confinement farms, $18 \%$ for seasonal pasture farms, and $12 \%$ for annual pasture farms. The phosphorous and protein were fed at $100 \%$ of National Research Council 
(NRC) recommendations. Corn grain, corn silage, dry hay, pasture, grass and alfalfa chopped and baled silage was produced on the farm. A soybean meal crude protein supplement, distiller grain and minerals were imported to the farm. A loader and mixer wagon were used for feeding grain and silage. A bale grinder was used for feeding hay.

The animal facilities for confinement and seasonal pasture included a double six parlor milking center, free stall barn naturally ventilated as cow housing, calf hutches and a dry lot as heifer housing, and short-term storage of premix feed. Bedding was chopped straw providing 1.4 kilograms per cow- day. The purchased bedding for the farms with an AD was reduced to 0.45 $\mathrm{kg}$ per cow-day because $0.95 \mathrm{~kg} / \mathrm{d}$ was recycled from the solid part of the digestate. The annual pasture-based system included a double-six parlor milking center, calf hutches and a dry lot as heifer housing with short-term storage for premix feed. No bedding was provided.

Corn and alfalfa were grown on each farm other than the annual pasture-based farm where only alfalfa and grass/legume pasture were grown. The land area for each crop production for each representative farm is shown on Table 2. The pasture was $70 \%$ cool-season grass and $30 \%$ legume mix pasture on the pasture-based farms. The soil was a medium sandy loam with total water holding capacity of $19 \mathrm{~cm}$ (7.5 in), and soil phosphorus at an optimum level between of 30 to $50 \mathrm{ppm}$. Alfalfa had a stand life of 4 years, and grass 10 years. The relative maturity index of corn was 100 days, with a plant population of 69,189 plants per hectare. The $\mathrm{P}$ and $\mathrm{K}$ balance was achieved with the manure application with a small, long-term build-up or drawdown. Twenty-eight kilograms per hectare of commercial nitrogen was applied to the corn at planting time. All manure was applied to land going to corn production. Nitrogen from legumes and manure applied by the grazing animals supplied the nutrients for the grass pasture. In the annual pasture-based system $80 \%$ of manure collected from the milking center was applied to grass and $20 \%$ to alfalfa.

Table 2

Manure was collected, stored and applied as a semi-solid (12-14\% DM), which represents fresh manure plus bedding. Total manure dry matter was the sum of manure excreted by the cows plus bedding and feed lost into the manure. Manure characteristics were based ASABE D384.2 standard (ASABE, 2014). In the confinement and seasonal pasture-based systems manure was collected with a scraper, stored in a top-loaded, clay-lined earthen basin and loaded 
in a slurry spreader tank with a slurry pump. The quantity of manure handled was dependent on the amount and type of bedding used and the amount of water contained in the manure. Six months manure storage capacity was provided on the farms with confinement housing, meaning storage was emptied twice each year in the spring and fall. Manure on the annual pasture farm was collected from the milking center with scraper bucket loading and short-term storage with a few days capacity (daily haul). Manure was imported to the seasonal pasture farm when an AD was used. $12,882 \mathrm{t} / \mathrm{yr}$ of manure was imported and applied to cropland along with 2,865 t/yr produced on the farm. Additional rented land ( $809 \mathrm{ha})$ was used to maintain the whole-farm nutrient balance.

\subsection{Economic information}

The economic analysis was performed by IFSM, which uses several economic equations with different factors for each system (e.g. facilities, machinery, land and crop, pasture,

livestock, custom operations), which can be found in the IFSM manual (Rotz et al, 2011). IFSM calculates a whole farm budget where the total cost of production is compared to income to predict the profit for the farm. The costs were related to resources grown on and brought onto the farm while income was received for milk, animals, and feed leaving the farm. All monetary returns from milk, feed, and animal sales occurred in the same year as well as the costs for producing those products. This annual accounting provided a measure of system performance that reflected one year's use of resources to produce that year's production (Rotz et al, 2011). The final economic analysis averages all the 26 weather years simulated by IFSM to determine the mean profit.

The budgeting process included operating and fixed costs of production. Operating costs included fuel, labor, electricity, fertilizers, seeds and all other important resource inputs. Fixed costs included machinery and facilities, which are converted from the initial dollar investment into an annual flow. Annual fixed costs were determined by amortizing initial capital costs over their designated life, which was 10 years for machinery and 20 years for structures (IRS publication 94b). A capital recovery factor with the designated life and discount rate of $6 \%$ was used to determine annual fixed costs. The capital recovery factor converts the initial capital cost into a stream of equal annual payments over the designated life of the fixed cost at a specified 
discount rate. Finally, annual fixed costs were summed with annual expenses to obtain a total production cost. The total production cost was subtracted from the total income received for milk, animal, and excess feed sales to determine the farm profit (Rotz et al., 2011).

Table 3 presents the major dairy costs and Appendix A.2 presents economic parameters used in all farms, which were obtained between the years 2011 and 2013 from USDA-NASS, USDA-NRCS, U.S Energy, Michigan Public Service, Michigan adverse effect wage rate (AEWR), Michigan State University Extension, Purdue University Extension and Iowa State University. The information in Appendix A.2 includes general economic parameters, cropping cost parameters, commodity price parameters, and custom operation parameters. General economic parameters specify the prices of energy inputs, the economic life and salvage values of machines and structures, labor wage, land rental, and the real interest rate. Cropping cost parameters include the cost of fertilizer, seed, and chemicals for producing each crop. Commodity price parameters include the buying prices of feeds and the selling prices for milk, animals and excess feed. Custom operation parameters describe the costs associated with hiring a custom operator to carry out specific farm operations. In this case, the hired custom operations were for corn grain harvest and planting, forage crop tillage and planting, and transport of manure from off farm to the AD.

Table 3

\section{Results and Discussion}

The IFSM model was used to analyze the transition from a 100-cow conventional confinement dairy to an annual pasture-based system. The analysis included economics, resource use and farm performance of five representative farms. The representative farms included yeararound confinement with conventional large-frame Holstein cattle; seasonal pasture with winter confinement and summer pasture with medium-frame Holsteins; an annual pasture-based dairy with New Zealand-style Friesian cattle whereby the cows were on pasture or open lots throughout the year; and the integration of an $\mathrm{AD}$ on a total confinement dairy and a seasonal pasture dairy with imported manure and an expanded land base for cash crop production and manure application.

The representative dairy systems were compared on a fixed land base (111 ha) with largemedium- and small-framed cattle, except the seasonal pasture with AD which had a land base of 
809 ha. The base farm for comparison included 100 large-frame cows (85 milking, 15 dry cows) with 80 replacements over 26 years of Lansing, MI weather. Based on the nutrient balance when producing alfalfa, corn silage and corn grain while importing some concentrate and returning the manure nutrients to the land for crop production, the nutrient balance with 100 large-frame cattle with replacements was similar to a seasonal pasture dairy with 142 medium-frame cattle and an annual pasture-based dairy with 160 small-frame cattle plus replacements.

3.1.Break-even point of a herd size for integrating an anaerobic digester into the dairy farm Currently, a herd size of 500 cows is considered the break-even point for a typical AD system for dairy farms (EPA, 2010). In this work, for comparison proposes the addition of an AD to the total confinement farm with 100 large-frame Holsteins resulted in an annual reduction of the net return to management and unpaid factors of more than $\$ 15,000$ per year. When an AD was added to a 500-cow, total confinement dairy there was an increase in net return to management and unpaid factors of about $\$ 10,000$ per year. Therefore, an analysis to find the break-even point for integrating an AD by using IFSM and the representative confinement farm with 500 lactating cows was performed. Figure 2 presents the net return per management and unpaid factors per cow of the farm with $\mathrm{AD}$ and the capital cost of the $\mathrm{AD}$ per cow in the $\mathrm{y}$-axis. As a result, 500 lactating cows in a confinement dairy farm approximates the point where the farmer will be able to cover all expenses with the incomes from the farm production. This result is aligned with EPA (2010) findings.

Figure 2

\subsection{Comparison of farm performance and resource use}

The transition from conventional confinement to a pasture-based system affected feed production and the purchase of feed supplements, milk and manure production. Overall, feed consumption increased $24 \%$ with the seasonal pasture and $15 \%$ with the annual pasture-based system compared to confinement because grazed forage was added to the cattle diet replacing high moisture grain and some alfalfa silage (seasonal pasture) and grain silage (annual pasture). On-farm feed production varied depending on the type of dairy and decreased from confinement to seasonal to annual pasture-based systems. The seasonal pasture produced $20 \%$ less milk per 
cow-yr compared to confinement and the annual pasture-based system produce $32 \%$ less per cow-yr. The confinement farms collected more manure than the seasonal and annual pasturebased farms because the cows stayed inside the barn year-around.

\subsubsection{Milk, feed and manure production}

The annual target milk production ( 305 day) without fat in the ration was $10,886 \mathrm{~kg} / \mathrm{cow}$ for the large-frame Holsteins, 9,071 kg/cow for the medium-frame Holsteins and 7,257 kg/cow for the small-frame New Zealand Friesians. The annual milk production with the feeds fed was $10,059 \mathrm{~kg} / \mathrm{cow}$ for the large-frame Holsteins, $8,079 \mathrm{~kg} / \mathrm{cow}$ for the medium-frame Holsteins and $6,847 \mathrm{~kg} / \mathrm{cow}$ for the small-frame New Zealand Friesians (Table 4). Because fat was not fed in the diet, forage quality was the limiting factor in milk production. Total annual milk production was $855,000 \mathrm{~kg}$ for the large-frame cattle, $975,182 \mathrm{~kg}$ with the medium-frame cattle and 931,223 $\mathrm{kg}$ with the small-frame cattle.

Table 4

The seasonal pasture produced 1,979 kg/cow-yr less milk and the pasture-based system produced 3,212 kg/cow-yr less milk than the confinement dairy. Generally, milk production per cow is lower on pasture-based than confinement systems (Winsten et al, 2000). Reduced milk production in pasture-based systems is usually because of the additional energy the cow expends in harvesting its own forage and the difficulty in balancing cow rations (Muller and Holden, 1994). Typically, the diets of grazing cattle are higher in forages and lower in grain and concentrate. The annual diet for the five representative farms is presented in Figure 3.

Figure 3

Feed consumption (including grazed forage) increased by $236 \mathrm{t} \mathrm{DM} / \mathrm{yr}$ with the seasonal pasture and $142 \mathrm{t} \mathrm{DM} / \mathrm{yr}$ with the pasture-based system compared to confinement (Table 4). In the seasonal pasture system there was no high moisture corn fed and $96 \mathrm{t} \mathrm{DM} / \mathrm{yr}$ less of alfalfa silage was fed compared to confinement; however, this was replaced by $279 \mathrm{t} \mathrm{DM} / \mathrm{yr}$ of grazed forage. In the annual pasture no high moisture corn or grain crop silage was included in the cattle diet but was replaced by $312 \mathrm{t}$ DM/yr of alfalfa silage, $183 \mathrm{tDM} / \mathrm{yr}$ of dry grain and $236 \mathrm{t} \mathrm{DM} / \mathrm{yr}$ of grazed forage.

Feed production varied with the cropping system. The confinement and pasture-based dairies produced more high and low quality hay (between 24 and $56 \mathrm{t} \mathrm{DM} / \mathrm{yr}$ ), and more alfalfa 
and grass silage (between 233 and $342 \mathrm{t} \mathrm{DM/yr).} \mathrm{The} \mathrm{seasonal} \mathrm{pasture} \mathrm{dairy} \mathrm{produced} 16 \mathrm{t}$ $\mathrm{DM} / \mathrm{yr}$ of high quality hay and $5 \mathrm{t} \mathrm{DM} / \mathrm{yr}$ of low quality hay because only 10 ha were allocated for alfalfa production. The confinement and annual pasture-based systems allocated 36 ha and 40 ha, respectively (Table 4).

The pasture-based system did not produce any grain. Grain crop silage production was similar for the confinement and seasonal pasture systems (between 371 and $375 \mathrm{t} \mathrm{DM} / \mathrm{yr}$ ) because the confinement dairy had 75 ha for corn production and the seasonal pasture had 51 ha available. The seasonal pasture with an expanded land for cash crop and AD produced 2,807 $\mathrm{t}$ $\mathrm{DM} / \mathrm{yr}$ of dry grain more than the confinement farm because of the increased cropland in corn (374 ha) and soybean (374 ha) ground. Because of the increased cropland the seasonal pasture with $\mathrm{AD}$ produced the greatest quantity of feed sold per year (2,936 t DM/yr) compared to the confinement (173 t/yr), seasonal pasture (57 t/yr) and the annual pasture-based systems (30 t/yr) (Table 4).

The confinement dairy purchased $227 \mathrm{t} \mathrm{DM} / \mathrm{yr}$ of feed compared to $395 \mathrm{t} \mathrm{DM} / \mathrm{yr}$ for the seasonal pasture and $480 \mathrm{t} \mathrm{DM/yr}$ for the annual pasture system (Figure 4). The reduction was primarily soybean meal and distillers grain, 77 and $36 \mathrm{t} \mathrm{DM} / \mathrm{yr}$ less compared to the seasonal pasture and 48 and $34 \mathrm{t} \mathrm{DM/yr} \mathrm{less} \mathrm{compared} \mathrm{to} \mathrm{the} \mathrm{annual} \mathrm{pasture-based} \mathrm{system,} \mathrm{respectively}$ (Table 4). Seventy-seven percent of the feed consumed on the confinement dairy was produced on-farm and $23 \%$ was purchased. The seasonal pasture system produced $67 \%$ of total feed consumed and $33 \%$ was purchased. The annual pasture dairy produced $57 \%$ of the total feed consumed and purchased $43 \%$. The seasonal pasture with expanded land for cash crop and AD system produced $67 \%$ of total feed consumed, $33 \%$ was purchased and the remaining crops were sold.

Figure 4

The confinement dairy collected more manure (2,881 wet t/yr) than the seasonal pasture $(2,865$ wet $t / y r)$ and annual pasture dairies $(2,459$ wet $t / y r)$ because the cows were confined in the barn throughout the year.

\subsection{Economics}


The evaluation of farm economics accounted for the major costs related to manure handling and production on-farm and their income from milk and animal sales. Main production costs analyzed on farm were: equipment, facilities, energy, labor, land rental, custom operations, crop production, feed costs and animal expenses. The analysis relates these costs with the type of dairy system (confinement, seasonal pasture or annual pasture-based) and the addition of an AD.

Overall, the seasonal pasture with imported manure, expanded land base for cash crop production and an integrated AD had the highest annual cost for manure handling $(\$ 211,629 / \mathrm{yr})$, followed by the confinement dairy with $\operatorname{AD}(\$ 62,757 / \mathrm{yr})$, seasonal pasture $(\$ 35,165 / \mathrm{yr})$, confinement $(\$ 35,0655 / \mathrm{yr})$ and annual pasture $(\$ 15,266 / \mathrm{yr})$, respectively. The seasonal pasture had the highest production cost $(\$ 483,987 / \mathrm{yr})$ followed by confinement with $\mathrm{AD}(\$ 455,225 / \mathrm{yr})$, confinement $(\$ 439,433 / \mathrm{yr})$ and annual pasture $(\$ 409,181 / \mathrm{yr})$. The seasonal pasture with imported manure, cash crop production and AD had the lowest production cost (\$226,982/yr) and the highest net return to management and unpaid factors $(\$ 351,415 / \mathrm{yr})$ followed by annual pasture $(\$ 116,048 / \mathrm{yr})$, seasonal pasture $(\$ 95,195 / \mathrm{yr})$, confinement $(\$ 78,224 / \mathrm{yr})$ and, confinement with AD (\$62,435/yr).

\subsubsection{Manure handling costs}

Manure was collected, stored and applied as a semi-solid (12-14\% DM). In the confinement and seasonal pasture systems manure was collected with a scraper, stored in a toploaded, clay-lined earthen basin with 6-month storage capacity and loaded in a slurry spreader tank with a slurry pump. The bedding was chopped straw supplied at 1.4 kilograms per cow- day for the confinement system and 0.5 kilograms per cow- day for the seasonal pasture system. For the annual pasture system, manure was collected only in the milking center with scraper bucket loading and short-term storage with a few days capacity (daily haul). No bedding was added on the pasture-based system.

The seasonal pasture with imported manure and an AD had the highest cost for manure handling, followed by confinement with anaerobic digestion, seasonal pasture, confinement, and annual pasture. In the confinement and seasonal pasture systems the annual costs for manure handling were: machinery, bedding, labor, storage, and fuel and electricity cost (Figure 5, Appendix A.6). The costs for the annual pasture were: machinery, labor and, fuel and electricity 
costs. There was no storage and bedding cost because manure was hauled daily and no bedding was provided.

Figure 5

The major costs for confinement with AD were storage $(\$ 24,062 / y r)$ and labor $(\$ 20,194 / y r)$. Storage cost increased 6 times $(\$ 20,119 / \mathrm{yr})$ and labor 5 times $(\$ 15,910 / y r)$ compared to confinement without AD. The storage cost increased because of the addition of the $\mathrm{AD}$, which included design, construction, installation, generator and digester. The total capital cost for the digester, generator and other equipment was $\$ 141,000 / y r$. Labor increased because 20 additional hours per week were required for maintenance of the digester.

The seasonal pasture with imported manure and AD followed a different trend than confinement and seasonal pasture. Total manure handling cost increased 6 times $(\$ 176,464 / \mathrm{yr})$ compared to the seasonal pasture without AD. Storage cost was $\$ 84,250 / y r$ greater than the same farm without an $\mathrm{AD}$ and imported manure because of the investment in the digester and related equipment (Appendix A.6). Machinery costs for hauling manure increased \$7,212/yr, fuel and electric cost increased $\$ 4,996 / y r$ and labor increased 4 times $(\$ 11,727 / y r)$ compared to the same farm without an $\mathrm{AD}$ and imported manure. The increase was from hauling the imported manure from the farm where was produced to the AD and then hauling and land application of the digestate. In addition, the seasonal pasture with imported manure and AD had the imported manure as fertilizer cost as an additional manure handling cost $(\$ 73,670 /$ year) compared to the other representative farms.

\subsubsection{Production costs}

The seasonal pasture had the highest production cost, followed by confinement with AD, confinement and annual pasture (Figure 6, Table 5). The seasonal pasture with AD had the lowest production cost.

\section{Figure 6}

Table 5

The major production costs in the confinement and seasonal pasture systems were for equipment, facilities, labor, seed, fertilizer and chemical and animal purchase and livestock expenses (Table 5). The seasonal pasture had higher facilities costs and animal purchase and livestock expenses compared to the confinement system because these costs increased with the 
number of cows. The confinement system had higher costs for labor, seed, fertilizer and chemicals because it had more cropland for corn and alfalfa production (111 ha) than the seasonal pasture (61 ha) due to the shift in land for grazing animals.

The transition from confinement to a seasonal pasture system increased production costs by $10 \%(\$ 44,554 / \mathrm{yr})$. The transition from confinement to annual pasture decreased production costs by $6 \%(\$ 30,252 / \mathrm{yr})$ (Table 5). The increase in production cost in the seasonal pasture system was because of the increase in purchased feed which was doubled (\$48,205/yr) compared to the confinement system. The seasonal pasture dairy purchased $77 \mathrm{t} \mathrm{DM} / \mathrm{yr}$ of soybean meal and $36 \mathrm{t} \mathrm{DM/yr}$ of distillers' grain more than the confinement system (Table 4) because of the decrease corn production and the change in diet, which included $23 \%$ of grazed forage.

The annual pasture dairy had production costs similar to the confinement system (Table 5). Although housing, machinery, manure handling and other costs decreased on the annual pasture dairy, net purchased feed cost increased $(\$ 92,982 / \mathrm{yr})$ with the purchase of $48 \mathrm{t} \mathrm{DM} / \mathrm{yr}$ more of soybean meal, 34 t DM/yr more distillers grain and 153 t DM/yr of dry grain (Table 4). These energy and protein feeds were needed to approach the target milk production level.

Animal purchase and livestock expenses increased by $44 \%(\$ 20,280 / y r)$ for the annual pasture dairy compared to the confinement dairy because of the increase in cow numbers. Most livestock expenses are related to the number of first lactation animals (Pasture-based Dairy Research and Education Facility, Michigan State University, 2013), therefore, high replacement rates are driven by the need to cull cows with recurrent health problems. Grazing cows tend to have fewer serious health problems and improved reproductive performance (Benbrook et al., 2010), therefore, for the annual pasture system $25 \%$ were first lactation animals and for the confinement system $35 \%$ were first lactation animals. Even though the annual livestock expenses were less (\$418/cow-yr) for the annual pasture system compared to the confinement system (\$551/cow-yr), total livestock expenses were higher for the annual pasture system because there were more animals on the farm.

Compared to confinement, the annual pasture-based system had the greatest reduction in the cost of seed, fertilizer and chemical $(66 \%, \$ 33,983 / \mathrm{yr})$, equipment cost (47\%, \$45,993/yr), energy cost $(24 \%, \$ 5,150 / \mathrm{yr})$, labor, $(1 \%, \$ 963 / \mathrm{yr})$, property tax $(28 \%, \$ 1,446 / \mathrm{yr})$ and, custom operation $(23 \%, \$ 707 / \mathrm{yr})$ because there was no grain crop production. There was a decrease of 
$32 \%$ ( $\$ 27,283 / \mathrm{yr})$ in facilities cost because the annual pasture-based system did not have a structure for cow housing (Table 5).

Production costs for the seasonal pasture with $\mathrm{AD}$ and additional land for cash cropping decreased $\$ 212,451 / \mathrm{yr}$ because of $\$ 863,596 / \mathrm{yr}$ decrease in net purchased feed and bedding cost compared to the confinement system. There were 2,936 t DM/yr feed sold compared to $173 \mathrm{t}$ $\mathrm{DM} / \mathrm{yr}$ sold by the confinement farm. The return from feed and cash crop sales more than offset the increased costs of custom hire, seed, fertilizer and chemicals, and land rental (Table 5).

The addition of the $\mathrm{AD}$ on the seasonal pasture farm with additional land for cash cropping increased facilities cost by $115 \%(97,835 / \mathrm{yr})$ and labor cost by $24 \%(\$ 17,562 / \mathrm{yr})$ compared to the seasonal pasture without AD. Energy cost decreased by $30 \%(\$ 6,463 / \mathrm{yr})$ compared to the seasonal pasture farm without $\mathrm{AD}$ and without an expanded land base. Comparing a seasonal pasture farm with cash crop and imported manure without AD with the representative seasonal pasture farm with expanded cash crop, imported manure and $\mathrm{AD}$ there was a reduction in energy cost by $67 \%(\$ 27,755 / \mathrm{yr})$. This included a $17 \%$ decrease $(\$ 1,298 / \mathrm{yr})$ in energy for manure handling for the reduction in the amount of purchased bedding from 1.4 $\mathrm{kg} / \mathrm{cow} / \mathrm{day}$ to $0.4 \mathrm{~kg} / \mathrm{cow} / \mathrm{day}$. There was a $33 \%$ ( $\$ 2,232 / \mathrm{yr})$ decrease in energy for milking and milk cooling related to water heating that was partially replaced by gas from the digester. Energy for animal housing, ventilation and lighting $(\$ 1,500 / y r)$ was completely offset the biogas produced by the $\mathrm{AD}$.

The major reduction of energy costs with the $\mathrm{AD}$ was a reduction of $24 \%(\$ 3,965 / \mathrm{yr})$ in electricity purchased (production of resource inputs). Additionally, there was 337,535 MBtu/yr more electricity produced than consumed by the farm, and this was sold. However, the selling price was the same as the buying price which over-estimated the farm selling price. The revenue from electricity sold was $\$ 9,451 / y r$.

The confinement system with $\mathrm{AD}$ experienced an increase in facilities costs of $24 \%$ $(\$ 20,130 / \mathrm{yr})$ and labor by $22 \%$ ( $\$ 15,894 / \mathrm{yr})$ due to the AD. Bedding costs decreased $67 \%$ $(\$ 5,538 / y r)$. Energy cost was reduced by $72 \%(\$ 15,379 / \mathrm{yr})$.

\subsubsection{Income and net return}

Income from milk sales was higher in the seasonal pasture system $(\$ 495,371 / \mathrm{yr})$ followed by confinement $(\$ 456,002 / \mathrm{yr})$ and the annual pasture $(\$ 444,822 / \mathrm{yr})$. The annual milk production 
of the farms was $8,079 \mathrm{~kg} / \mathrm{cow}$ for the seasonal pasture system, $10,059 \mathrm{~kg} / \mathrm{cow}$ for the confinement system and 6,847 kg/cow for the annual pasture-based system. Even though the confinement had higher milk production per cow, the income from milk sales was higher for seasonal pasture farm because it had more lactating cows than the confinement farm.

Income from animal sales increased 36\% (\$22,155/yr) with the seasonal pasture system and $30 \%(\$ 18,752 / y r)$ with the annual pasture-based system compared to confinement (Table 6). The difference was related to the culling rate; $25 \%$ for the seasonal pasture, $30 \%$ for the annual pasture, and $35 \%$ for the confinement system.

Table 6

Return to management and unpaid factors varied depending on the farming system (Table 6). The seasonal pasture with AD and cash crop production had the greatest net return to management and unpaid factors, followed by the annual pasture, seasonal pasture, confinement and confinement with AD (Figure 7). Seasonal pasture with additional land for cash cropping and $\mathrm{AD}$ had the highest net return because it had the lowest production cost $(\$ 226,982 / \mathrm{yr})$ and a high income from milk (\$494,587/yr) and animal sales $(\$ 83,810 / \mathrm{yr})$ which were $48 \%$ less, and $8 \%$ and $36 \%$ more, respectively, than the confinement dairy (Figure 8). The farm had a net return to management and unpaid factors of $\$ 256,220 / \mathrm{yr}$ greater than the seasonal pasture dairy, indicating returns from both the AD and cash crop sales (Figure 7).

The confinement farm with AD had the lowest net return to management and unpaid factors because of the high production cost $(\$ 455,225 / \mathrm{yr})$ which included an increase of $\$ 15,792$ per year from the AD (Figure 8). The addition of the AD on the confinement farm reduced the net return to management and unpaid factors by $\$ 15,789 / \mathrm{yr}$ (Figure 7).

The annual pasture and seasonal pasture had similar net returns (Table 6). The confinement system had a lower net return to management and unpaid factors compared to the annual pasture and seasonal pasture systems because it had \$18,752/yr and $\$ 22,155 /$ yr less income from animal sales, respectively.

Figure 7

Figure 8 


\section{Conclusions}

Five representative dairy production systems were compared to evaluate resource use and conservation, and the economic impacts in the transition from total confinement to seasonal-and annual-pasture based systems. The available land base on four farms was held constant at 111 ha, which was the area needed to support 100 large Holstein cows plus replacements with small annual shortage or excess of feed, and a near-balance of phosphorous and potassium from manure cycling on the farm. The land base of a seasonal pasture system was expanded to 809 ha to provide additional land for cash crop production and land application of imported manure used to operate an AD. Anaerobic digestion was evaluated on the confinement and seasonal pasture dairies.

1. Based on a whole-farm nutrient balance, the 111 ha land base supported 100 large-frame $(726 \mathrm{~kg})$ Holsteins cows on the total confinement farm, 142 medium-frame (590 kg) cows on the seasonal pasture dairy, and 160 small-frame $(454 \mathrm{~kg})$ New Zealand type cows with replacements on the annual pasture dairy.

2. The annual pasture-based system had the greatest net return to management and unpaid factors followed by the seasonal pasture and confinement systems. Compared to the total confinement system, net income on the annual pasture increased $48 \%$ and $22 \%$ on the seasonal pasture.

3. The addition of an $\mathrm{AD}$ on the 100-cow total confinement dairy decreased the net return to management and unpaid factors by $20 \%$.

4. When anaerobic digestion was added to the seasonal pasture with an increased land base for cash crop production and an imported manure volume equivalent to a 500-cow dairy, the net return to management and unpaid factors increased $269 \%$ compared to the seasonal pasture dairy alone. Facility and structure costs increased 115\%, manure handling and related labor costs increased $287 \%$, but bedding costs decreased $67 \%$ and energy costs decreased $32 \%$. Net purchased feed and bedding costs decreased $1073 \%$ mainly because of the sale of cash crops; therefore, $\mathrm{AD}$ on the seasonal pasture farm was primarily paid for from the sales of cash crops. 


\section{Acknowledgements}

This work is supported by the USDA National Institute of Food and Agriculture, Hatch project MICL02359.

\section{References}

Anaerobic Digestion Research and Education Center, M.S.U., 2013. No Title [WWW Document]. Michigan State Univ. URL

https://www.egr.msu.edu/bae/adrec/feature/anaerobic-digestion-research-and-educationcenter

ASABE (American Society of Agricultural and Biological Engineers), 2015a. ASAE EP496.3 Agricultural Machinery Management Data.

ASABE (American Society of Agricultural and Biological Engineers), 2015b. ASAE D497.7 Agricultural Machinery Management Data.

ASABE (American Society of Agricultural and Biological Engineers), 2014. ASAE D384.2 Manure Production and Characteristics.

Aschmann, S., Cropper, J.B., 2007. Profitable grazing-based dairy systems. Range and Pasture Technical Note No. 1, Natural Resources Conservation Service, U.S. Department of Agriculture.

Benbrook, C., Carman, C., Clark, E., Daley, C., 2010. A dairy farm's footprint: evaluating the impacts of conventional and organic farming systems, The Organic Center.

Betts, C., Ling, C., 2009. Cooperative Approaches for Implementation of Dairy Manure Digesters, USDA Research Report 217.

Bishop, C.P., Shumway, C.R., 2009. The economics of dairy anaerobic digestion with coproduct marketing. Rev. Agric. Econ. 31, 394-410.

Burke, D.A., 2001. Dairy Waste Anaerobic Digestion Handbook, Environmental Energy Company.

Castillo, A.R., 2009. Whole-farm nutrient balances are an important tool for California dairy farms [WWW Document]. California Agriculture, University of California, Volume 63: Number 3. URL https://ucanr.edu/repositoryfiles/ca6303p149-72524.pdf.

Chen, Y., Yang, G., Sweeney, S., Feng, Y., 2010. Household biogas use in rural China: A study of opportunities and constraints. Renew. Sustain. Energy Rev. 14, 545-549.

EPA (US Environmental Protection Agency), 2015. Ag 101: Dairy Production.

EPA (US Environmental Protection Agency), 2013. Livestock Anaerobic Digester Database [WWW Document]. URL https://www.epa.gov/agstar/livestock-anaerobic-digesterdatabase 
EPA (US Environmental Protection Agency), 2010. Anaerobic Digestion Capital Costs for Dairy Farms, AgSTAR.

EPA (U.S. Environmental Protection Agency), 1999. Livestock Manure Management [WWW Document]. URL http://www.epa.gov/methane/reports/05-manure.pdf (accessed 4.2.14).

FAO (Food and Agriculture Organization of the United Nations), 2016. Milk production [WWW Document]. Dairy Prod. Prod. URL http://www.fao.org/agriculture/dairy-gateway/milkproduction/en/\#.VtCK0_krKUk.

Gerber, P.J., Steinfeld, H., Henderson, B., Mottet, A., Opio, C., Dijkman, J., Falcucci, A., Tempio, G., 2013. Tackling climate change through livestock: A global assessment of emissions and mitigation opportunities. FAO, Rome.

Ghafoori, E., Flynn, P.C., 2007. Optimizing the size of anaerobic digesters. Trans. ASABE 50, $1029-1036$.

Goodrich, P., 2005. Anaerobic Digester Systems for Mid-Sized Dairy Farms, The Minnesota Project. Minnesota.

Hadrich, J.C., Harrigan, T.M., Wolf, C.A., 2010. Economic comparison of liquid manure transport and land application. ASABE 26, 743-758.

Hadrich, J.C., Wolf, C.A., 2011. Citizen complaints and environmental regulation of Michigan livestock operations. J. Anim. Sci. 89, 277-286.

Harrigan, T.M., 2010. Liquid manure hauling capacity of custom applicators using tank spreader systems. ASABE 26, 729-742.

Heckman, E., Hinds, S., Johnson, K., Perkins, J., 2007. Management-Intensive Grazing in Indiana. Indiana, U.S.

Holm-Nielsen, J.B., Al Seadi, T., Oleskowicz-Popiel, P., 2009. The future of anaerobic digestion and biogas utilization. Bioresour Technol, 100, 5478-5484.

IEA Bioenergy, 2005. Biogas Production and Utilisation. International Energy Agency.

IEA Bioenergy, 2006. Biogasmax, Biogas production and utilisation [WWW Document]. URL http://www.biogasmax.eu/media/2_biogas_production_utilisation_068966400_1207_1904 2007.pdf.

Iowa State University, 2010. i-farmtools. Short I-FARM description [WWW Document]. URL http://i-farmtools.iastate.edu/i-farm/I-FARM_short_description.asp (accessed 6.11.13).

Koelsch, R and Lesoing, G., 1999. Nutrient balance on Nebraska livestock confinement systems. J. Anim. Sci. 77(2), 63-71.

Kriegl, T., McNair, R., 2005. Pastures of plenty: Financial performance of Wisconsin grazing dairy farms. University of Wisconsin-Madison, Madison.

Lazarus, W.F., 2009. Economic Analysis ofthe Jer-Lindy Farms Anaerobic Digester [WWW Document]. Minnesota Proj. URL 
http://mnproject.org/pdf/LCMR_Digester_factsheet_economics.pdf

Lazarus, W.F., Rudstrom, M., 2007. The economics of anaerobic digester operation on a Minnesota dairy farm. Rev. Agric. Econ. 29, 349-364.

Lettinga, G., Van Haandel, A., 1992. Anaerobic Digestion for Energy Production and Environmental Protection. Chapter 19 in Renewable Energy: Sources for Fuels and Electricity. Covelo, CA: Island Press. pp. 817-839.

Loucks, D.P., Beek, E., 2005. Modelling Methods for Evaluating Alternatives, in: Loucks, D.P., Beek, E. (Eds.), Water Resources Systems Planning and Management: An Introduction to Methods, Models and Applications. United Nations Educational, Scientific and Cultural Organization, The Netherlands, pp. 59-77.

Maria, A., 1997. Introduction to modeling and simulation. Proc. 29th Conf. Winter Simul. WSC '97 7-13.

Millen, G., 2008. Small-scale digester boosts farm economics. Biocycle 49, 46-47.

Moller, H.B., Hansen, J.D., Sorensen, C.A.G., 2007. Nutrient recovery by solid-liquid separation and methane productivity of solids. ASABE 50, 193-200.

Mott, G.O., 1974. Nutrient recycling in pastures. Forage Fertil. 323-339.

Muller, L.D., Holden, L.A., 1994. Intensive Rotazional Grazing. Large Anim. Vet. 27-29.

Nelson, C., Lamb, J., 2002. Final Report: Haubenschild Farms Anaerobic Digester. Minnesota.

Nott, S., 2003. Evolution of dairy grazing in the 1990's. Department of Agricultural Economics Staff Paper No. 2003-07, Michigan State University, East Lansing, Michigan.

Pasture-based Dairy Research and Education Facility, M.S.U., 2013. No Title [WWW Document]. Michigan State Univ. URL http://pasturedairy.kbs.msu.edu/

Powell, J.M., McCrory, D.F., Jackson-Smith, D.B., Saam, H., 2005. Manure collection and distribution on Wisconsin dairy farms. J. Environ. Qual. 34, 2036-2044.

Rojas-Downing, M.M., 2013. Resource use and conservation and environmental impacts in the transition from confinement to pasture-based dairies. Thesis, Michigan State University, East Lansing, Michigan.

Rayburn, E.B., 2007. Forage utilization for pasture-based livestock production. Natural Resource, Agriculture, and Engineering Service (NRAES), New York.

Roos, K.F., Martin Jr., J.B., Moser, M.A., 2004. A Manual For Developing Biogas Systems at Commercial Farms in the United States, AgSTAR Handbook.

Rota, A; Sperandini, S., 2007. Integrated crop-livestock farming systems, IFAD Livestock Thematic Papers. Rome, Italy.

Rotz, C.A., Corson, M.S., Chianese, D.S., Hafner, S.D., Jarvis, R., Coiner, C.U., 2011. The integrated farm system model - Reference Manual - Version 3.6. 
Rotz, C.A., Hafner, S.D., 2011. Whole farm impact of anaerobic digestion and biogas use on a New York dairy farm. ASABE Annual International Meeting. Paper No. 1111194.

Rotz, C.A., Soder, K.J., Skinner, R.H., Dell, C.J., Kleinman, P.J., Schmidt, J.P., and Bryant, R.B., 2009. Grazing Can Reduce the Environmental Impact of Dairy Production Systems. Forage and Grazinglands.

Russelle, M.P., Entz, M.H., Franzluebbers, A.J., 2007. Reconsidering integrated crop-livestock systems in North America. Agron. J. 99, 325-334.

Russelle, M.P., Franzluebbers, A.J., 2007. Introduction to "Symposium: Integrated croplivestock systems for profit and sustainability.” Agron. J. 99, 323-324.

Sendich, E., 2008. Modeling and Analysis of the Biorefinery Integrated with the Agricultiral Landscape. Michigan State University.

Steinfeld, H., Gerber, P., Wassenaar, T., Castel, V., Rosales, M., Haan, C., 2006. Livestock's long shadow: environmental issues and options. FAO, Rome.

Sulc, R.M., Franzluebbers, A.J., 2014. Exploring integrated crop - livestock systems in different ecoregions of the United States. Eur. J. Agron. 57, 21-30.

Teenstra, E., Vellinga, T., Aektasaeng, N., Amatayakul, W., Ndambi, A., Pelster, D., Germer, L., Jenet, A., Opio, C., Andeweg, K. 2014. Global Assessment of Manure Management Policies and Practices. Wageningen, Wageningen UR (University \& Research centre) Livestock Research, Livestock Research Report 844.

The University of Tasmania, 2013. Dairy Greenhouse gas Abatement Strategy calculator. User Manual. The Department of Agriculture, Fisheries and Forestry.

U.S. Census Bureau, 2012. Statistical Abstract of the United States:2012, Section 17 Agriculture.

United Dairy Industry of Michigan, 2016. Dairy Facts [WWW Document]. URL http://www.milkmeansmore.org/print/36

USDA, EPA, DOE, 2014. Biogas Opportunities Roadmap: Voluntary Actions to Reduce Methane Emissions and Increase Energy Independence.

USDA-ERS (United States Department of Agriculture- Economic Research Service), 2016. Milk cows and production by State and region [WWW Document]. URL http://www.ers.usda.gov/data-products/dairy-data.aspx

USDA-NASS (United States Department of Agriculture-National Agricultural Statistics Service), 2014. Milk Cows and Production Final Estimates 2008-2012, Statistical Bulletin Number 1036.

Wattiaux, M. A, Karg, K.L., 2004. Protein level for alfalfa and corn silage-based diets: II. Nitrogen balance and manure characteristics. J. Dairy Sci. 87, 3492-3502.

Weiland, P., 2010. Biogas production: current state and perspectives. Appl Microbiol Biotechnol, 85, 849-860. 
Whitehead, D.C., 1995. Grassland nitrogen. CABI, Wallingford, United Kingdom.

Wilkins, R. J. 2000. Forages and their role in animal systems. Forage Evaluation in Ruminant Nutrition. (Ed. D. I. Givens, E. Owen, R. F. E. Axford and H. M. Omed). CAB Publishing. Wallingford, UK. pp. 1-14.

Winsten, J.R., Parsons, R.L., Hanson, G.D., 2000. Differentiated dairy grazing intensity in the Northeast. J. Dairy Sci. 83, 836-842. 
Table 1. Anaerobic digester parameters

\begin{tabular}{|c|c|c|c|}
\hline & Unit & Confinement & $\begin{array}{l}\text { Seasonal Pasture } \\
\mathrm{w} / \mathrm{AD}^{[a]}\end{array}$ \\
\hline Manure collected on farm & wet t/yr (wet ton/yr) & $2,831(3,121)$ & $2,865(3,158)$ \\
\hline Manure imported to farm & wet $\mathrm{t} / \mathrm{yr}$ (wet ton/yr) & 0 & $12,882(14,200)$ \\
\hline Moisture content & $\%$ & 90 & 90 \\
\hline Volatile solids (VS) & $\%$ & 80 & 80 \\
\hline Total solids (TS) & $\%$ & 10 & 10 \\
\hline $\mathrm{VS} / \mathrm{TS}(\%$ of TS) & $\%$ & 80 & 80 \\
\hline $\mathrm{CH}_{4}$ content & $\%$ & 55 & 55 \\
\hline Heat of combustion & $\mathrm{kJ} /$ mole methane & 890 & 890 \\
\hline \multicolumn{4}{|l|}{ Digester } \\
\hline Initial cost purchase price $e^{[b]}$ & $\$$ & 117,000 & 539,000 \\
\hline Repair and maintenance cost & $\%$ of initial cost & 2 & 2 \\
\hline Biogas leakage & $\%$ of gas produced & 15 & 15 \\
\hline $\begin{array}{l}\text { Volatile solids conversion } \\
\text { efficiency } \\
\text { Generator and other Equipme }\end{array}$ & $\%$ of initial volatile solids & 35 & 35 \\
\hline Generator capital cost ${ }^{[\mathrm{b}]}$ & $\$$ & 59,000 & 270,000 \\
\hline $\begin{array}{l}\text { Repair and maintenance cost } \\
(\$ 0.015 / \mathrm{kWh})\end{array}$ & $\$ /$ year & 1,755 & 7,920 \\
\hline Annual repair and maintenance & $\%$ of initial equipment cost & 3 & 3 \\
\hline Operation labor requirement & $\mathrm{h} /$ week & 20 & 20 \\
\hline Electric generation equipment & $\mathrm{kW}$ & 17 & 77 \\
\hline Electric generator efficiency & $\%$ of energy input & 35 & 35 \\
\hline Run time efficiency & $\%$ of total time & 85 & 85 \\
\hline Biogas used for water heating & $\%$ of gas produced & 40 & 40 \\
\hline $\begin{array}{l}\text { Total digester, generator and } \\
\text { other equipment } \\
\text { Energy }\end{array}$ & $\$$ & 176,000 & 809,000 \\
\hline Gross energy from biomass & MMBtu/yr & 1,143 & 5,173 \\
\hline $\begin{array}{l}\text { Net energy from electricity } \\
\text { including efficiency }\end{array}$ & MMBtu/yr & 400 & 1,810 \\
\hline Transportation waste energy & MMBtu/yr & 2 & 8 \\
\hline Energy for heating influent & MMBtu/yr & 213 & 963 \\
\hline Energy to operate AD & MMBtu/yr & 57 & 259 \\
\hline $\begin{array}{l}\text { Heat production from } \\
\text { generator }\end{array}$ & MMBtu/yr & 594 & 2,690 \\
\hline Total net energy $^{[\mathrm{c}]}$ & MMBtu/yr & 178 & 806 \\
\hline
\end{tabular}

[a] Seasonal pasture with imported manure, cash crop and AD 
[b]Structure economic life is 20 years, and real interest rate is $6 \%$

[c] Total net energy accounting for all operational needs including transportation, biomass availability, influent heat, digester heat, digester operation, digester operational time, generator efficiency, and generator operational time 
Table 2. Major descriptive parameters of five representative dairy production systems

\begin{tabular}{|c|c|c|c|c|c|c|}
\hline & Unit & $\begin{array}{l}\text { Confine } \\
\text { ment }\end{array}$ & $\begin{array}{l}\text { Confinem } \\
\text { ent } \mathrm{w} / \\
\mathrm{AD}^{[\mathrm{a}]} \\
\end{array}$ & $\begin{array}{l}\text { Seasonal } \\
\text { Pasture }\end{array}$ & $\begin{array}{l}\text { Seasonal } \\
\text { Pasture } \\
\mathrm{w} / \mathrm{AD}^{[\mathrm{b}]} \\
\end{array}$ & $\begin{array}{l}\text { Annual } \\
\text { Pasture }\end{array}$ \\
\hline \multicolumn{7}{|l|}{ Livestock } \\
\hline Lactating cows & - & 100 & 100 & 142 & 142 & 160 \\
\hline $\begin{array}{l}\text { Young stock over } \\
\text { one year }\end{array}$ & - & 38 & 38 & 54 & 54 & 61 \\
\hline $\begin{array}{l}\text { Young stock under } \\
\text { one year }\end{array}$ & - & 42 & 42 & 60 & 60 & 67 \\
\hline \multicolumn{7}{|l|}{ Alfalfa } \\
\hline Land area & ha (ac) & $36.4(90)$ & $\begin{array}{l}36.4 \\
(90)\end{array}$ & $\begin{array}{l}10.1 \\
(25)\end{array}$ & $\begin{array}{l}10.1 \\
(25)\end{array}$ & $\begin{array}{l}40.5 \\
(100)\end{array}$ \\
\hline Harvest system & - & $\begin{array}{l}\text { Hay and } \\
\text { silage }\end{array}$ & $\begin{array}{l}\text { Hay and } \\
\text { silage }\end{array}$ & $\begin{array}{l}\text { Hay and } \\
\text { silage }\end{array}$ & $\begin{array}{l}\text { Hay and } \\
\text { silage }\end{array}$ & $\begin{array}{l}\text { Hay and } \\
\text { silage }\end{array}$ \\
\hline Number of cuttings & - & 4 & 4 & 4 & 4 & 4 \\
\hline Avg. yield & $\begin{array}{l}\text { t DM/ha } \\
\text { (ton } \\
\text { DM/ac) }\end{array}$ & $\begin{array}{l}11.8 \\
(5.3)\end{array}$ & $\begin{array}{l}11.8 \\
(5.3)\end{array}$ & $11.6(5.2)$ & $\begin{array}{l}11.6 \\
(5.2)\end{array}$ & $\begin{array}{l}11.6 \\
(5.2)\end{array}$ \\
\hline \multicolumn{7}{|l|}{ Corn } \\
\hline $\begin{array}{l}\text { Land area for } \\
\text { confinement }\end{array}$ & ha (ac) & $\begin{array}{l}74.8 \\
(185)\end{array}$ & $\begin{array}{l}74.8 \\
(185)\end{array}$ & $\begin{array}{l}50.6 \\
(125)\end{array}$ & $\begin{array}{l}374 \\
(925)\end{array}$ & 0 \\
\hline Harvest system & - & $\begin{array}{l}\text { Grain, } \\
\text { silage }\end{array}$ & $\begin{array}{l}\text { Grain, } \\
\text { silage }\end{array}$ & $\begin{array}{l}\text { Grain, } \\
\text { silage }\end{array}$ & $\begin{array}{l}\text { Grain, } \\
\text { silage }\end{array}$ & - \\
\hline Number of cuttings & - & 1 & 1 & 1 & 1 & - \\
\hline Avg. dry corn yield & $\begin{array}{l}\text { t DM/ha } \\
\text { (ton } \\
\text { DM/ac) }\end{array}$ & $\begin{array}{l}6.4 \\
(2.9)\end{array}$ & $\begin{array}{l}6.4 \\
(2.9)\end{array}$ & $\begin{array}{l}6.0 \\
(2.7)\end{array}$ & $\begin{array}{l}6.2 \\
(2.8)\end{array}$ & - \\
\hline $\begin{array}{l}\text { Avg. high moisture } \\
\text { yield }\end{array}$ & $\begin{array}{l}\text { t DM/ha } \\
\text { (ton } \\
\text { DM/ac) }\end{array}$ & $\begin{array}{l}6.1 \\
(2.7)\end{array}$ & $\begin{array}{l}6.1 \\
(2.7)\end{array}$ & - & - & - \\
\hline Avg. silage yield & $\begin{array}{l}\text { t DM/ha } \\
\text { (ton } \\
\text { DM/ac) }\end{array}$ & $\begin{array}{l}12.7 \\
(5.7)\end{array}$ & $12.6(5.6)$ & $12.9(5.8)$ & $\begin{array}{l}13.8 \\
(6.1)\end{array}$ & - \\
\hline \multicolumn{7}{|l|}{ Grass } \\
\hline Land area & ha (ac) & 0 & 0 & $\begin{array}{l}50.6 \\
(125)\end{array}$ & $\begin{array}{l}50.6 \\
(125)\end{array}$ & $\begin{array}{l}70.8 \\
(175)\end{array}$ \\
\hline Harvest system & - & - & - & Silage & Silage & Silage \\
\hline Number of cuttings & - & - & - & 1 & 1 & 1 \\
\hline Avg. yield & $\begin{array}{l}\text { t DM/ha } \\
\text { (ton } \\
\text { DM/ac) }\end{array}$ & - & - & $\begin{array}{l}3.8 \\
(1.7)\end{array}$ & $\begin{array}{l}4.1 \\
(1.8)\end{array}$ & $\begin{array}{l}3.8 \\
(1.7)\end{array}$ \\
\hline
\end{tabular}

[a] Confinement with AD

[b] Seasonal pasture with imported manure, cash crop and AD 
Table 3. Major dairy costs $(\$ /$ cow-year)

\begin{tabular}{llll}
\hline & Confinement & Seasonal Pasture & Annual Pasture \\
\hline Cow housing $^{[\mathrm{a}]}$ & $\$ 1,400$ & $\$ 1,380$ & 0 \\
Heifer housing $^{[\mathrm{b}]}$ & $\$ 267$ & $\$ 264$ & $\$ 267$ \\
Milking center $^{[\mathrm{c}]}$ & $\$ 3,120$ & $\$ 2,197$ & $\$ 1,950$ \\
Feed facility $^{[\mathrm{d}]}$ & $\$ 45$ & $\$ 44$ & $\$ 45$ \\
Livestock expenses $^{[\mathrm{e}]}$ & $\$ 551$ & $\$ 359$ & $\$ 418$ \\
\hline Total & $\$ 5,383$ & $\$ 4,244$ & $\$ 2,680$ \\
\hline
\end{tabular}

[a] Free stall barn, naturally ventilated

[b] Calf hutches and dry lot

[c] Double six parlor

[d] Short term storage of premix

[e] Includes veterinary and medication, semen and breeding, animal and milking supplies, insurance of animals, utilities for milking and animal handling, animal hauling and DHIA, registration 
Table 4. Average annual milk, feed and manure production of five representative dairy production systems

\begin{tabular}{|c|c|c|c|c|c|c|}
\hline & & Confinement & $\begin{array}{l}\text { Confinement } \\
\mathrm{w} / \mathrm{AD}^{[\mathrm{a}]}\end{array}$ & $\begin{array}{l}\text { Seasonal } \\
\text { Pasture }\end{array}$ & $\begin{array}{l}\text { Seasonal } \\
\text { Pasture } \\
\mathrm{w} / \mathrm{AD}^{[b]}\end{array}$ & $\begin{array}{l}\text { Annual } \\
\text { Pasture }\end{array}$ \\
\hline Manure handled & t DM/yr & 2,881 & 2,831 & 2,865 & 13,855 & 2,459 \\
\hline Milk production & $\mathrm{kg} /$ cow-yr & 10,059 & 10,059 & 8,079 & 8,067 & 6,847 \\
\hline \multicolumn{7}{|c|}{ Feed and grain production } \\
\hline High-quality hay & $\mathrm{t} \mathrm{DM} / \mathrm{yr}$ & 46 & 46 & 16 & 15 & 56 \\
\hline Low-quality hay & $\mathrm{t} \mathrm{DM} / \mathrm{yr}$ & 28 & 28 & 5 & 5 & 24 \\
\hline Alfalfa/grass silage & $\mathrm{t} D M / y r$ & 233 & 233 & 93 & 101 & 342 \\
\hline Grain crop silage & $\mathrm{t} \mathrm{DM} / \mathrm{yr}$ & 374 & 374 & 371 & 375 & - \\
\hline High moisture grain & $\mathrm{t} \mathrm{DM} / \mathrm{yr}$ & 151 & 151 & - & - & - \\
\hline Dry grain & $\mathrm{t} D M / y r$ & 81 & 77 & 100 & 2,888 & - \\
\hline Total produced & $\mathrm{t} \mathrm{DM} / \mathrm{yr}$ & 913 & 909 & 585 & 3,383 & 423 \\
\hline \multicolumn{7}{|l|}{ Feed and grain sold } \\
\hline Alfalfa Silage & $\mathrm{t} D M / y r$ & 55 & 57 & 12 & 27 & 30 \\
\hline Hay & $\mathrm{t} D M / y r$ & 43 & 43 & - & - & - \\
\hline Grain silage & $\mathrm{t} D M / y r$ & 75 & 74 & 1 & 11 & - \\
\hline $\begin{array}{l}\text { Cash crop corn and } \\
\text { soybeans }\end{array}$ & $\mathrm{t} \mathrm{DM} / \mathrm{yr}$ & - & - & - & 852 & - \\
\hline Dry grain & $\mathrm{t} D M / y r$ & - & - & 44 & 2,047 & - \\
\hline Total sold & $\mathrm{t} D M / y r$ & 173 & 175 & 57 & 2,936 & 30 \\
\hline \multicolumn{7}{|l|}{ Feed purchased } \\
\hline Hay purchased & $\mathrm{t} \mathrm{DM} / \mathrm{yr}$ & - & - & 84 & 48 & 18 \\
\hline Dry grain & $\mathrm{t} \mathrm{DM} / \mathrm{yr}$ & 30 & 34 & - & - & 183 \\
\hline Soybean meal $48 \%$ & t DM/yr & 20 & 22 & 97 & 98 & 68 \\
\hline Distillers grain & t DM/yr & 171 & 171 & 207 & 216 & 205 \\
\hline Mineral and vitamin & t DM/yr & 6 & 6 & 6 & 6 & 5 \\
\hline Total purchased & $\mathrm{t} \mathrm{DM} / \mathrm{yr}$ & 227 & 232 & 395 & 368 & 480 \\
\hline \multicolumn{7}{|l|}{ Feed consumed } \\
\hline Grazed forage & $\mathrm{t} D M / y r$ & - & - & 279 & 295 & 236 \\
\hline Hay & $\mathrm{t} D M / y r$ & 32 & 59 & 105 & 68 & 99 \\
\hline Alfalfa silage & $\mathrm{t} \mathrm{DM} / \mathrm{yr}$ & 178 & 220 & 82 & 91 & 312 \\
\hline Grain crop silage & $\mathrm{t} \mathrm{DM} / \mathrm{yr}$ & 298 & 359 & 370 & 334 & - \\
\hline High moisture grain & $\mathrm{t} D M / y r$ & 151 & 151 & - & - & - \\
\hline Dry grain & $\mathrm{t} D M / y r$ & 111 & 111 & 55 & 841 & 183 \\
\hline Distillers grain & $\mathrm{t} D M / y r$ & 171 & 171 & 207 & 216 & 205 \\
\hline Soybean meal $48 \%$ & $\mathrm{t} \mathrm{DM} / \mathrm{yr}$ & 20 & 22 & 97 & 98 & 68 \\
\hline Mineral and vitamin & $\mathrm{t} \mathrm{DM} / \mathrm{yr}$ & 6 & 6 & 6 & 6 & 5 \\
\hline Total consumed & $\mathrm{t} \mathrm{DM} / \mathrm{yr}$ & 966 & 967 & 1,202 & 1,110 & 1,109 \\
\hline
\end{tabular}

[a] Confinement with AD

[b] Seasonal pasture with imported manure, cash crop, expanded land base and AD 
Table 5. Total production costs (\$/year) for five representative dairy production systems

\begin{tabular}{|c|c|c|c|c|c|}
\hline & Confinement & $\begin{array}{l}\text { Confinement } \\
\mathrm{w} / \mathrm{AD}^{[\mathrm{a}]}\end{array}$ & $\begin{array}{l}\text { Seasonal } \\
\text { Pasture }\end{array}$ & $\begin{array}{l}\text { Seasonal Pasture } \\
\mathrm{w} / \mathrm{AD}^{[\mathrm{b}]}\end{array}$ & $\begin{array}{l}\text { Annual } \\
\text { Pasture }\end{array}$ \\
\hline Equipment & 98,047 & 97,231 & 97,386 & 93,014 & 52,054 \\
\hline Facilities & 84,882 & 105,012 & 85,245 & 183,080 & 57,599 \\
\hline Energy & 21,270 & 5,891 & 20,207 & 13,744 & 16,120 \\
\hline Labor & 72,594 & 88,488 & 65,439 & 83,001 & 71,631 \\
\hline Custom operation & 3,087 & 3,070 & 3,295 & 97,675 & 2,380 \\
\hline Imported manure as fertilizer & - & - & - & 73,670 & - \\
\hline Seed, fertilizer and chemical & 51,111 & 51,111 & 38,950 & 340,373 & 17,128 \\
\hline Land rental & 5,270 & 5,270 & 5,270 & 96,178 & 5,270 \\
\hline Net purchased feed and bedding & 27,401 & 23,380 & 85,929 & $(836,195)$ & 92,982 \\
\hline $\begin{array}{l}\text { Animal purchase and livestock } \\
\text { expense }\end{array}$ & 46,600 & 46,600 & 50,978 & 50,978 & 66,880 \\
\hline Milk hauling and marketing fees & 23,998 & 23,999 & 26,070 & 26,029 & 23,410 \\
\hline Property tax & 5,173 & 5,173 & 5,218 & 5,435 & 3,727 \\
\hline Total production costs & 439,433 & 455,225 & 483,987 & 226,982 & 409,181 \\
\hline
\end{tabular}

[a] Confinement with AD

[b] Seasonal pasture with imported manure, cash crop and AD

Table 6. Income and production costs (\$/year) for five representative dairy production systems 


\begin{tabular}{llllll}
\hline & \multirow{2}{*}{ Confinement } & $\begin{array}{l}\text { Confinement } \\
\mathrm{w}^{\text {A AD }}\end{array}$ & $\begin{array}{l}\text { Seasonal } \\
\text { Pasture }\end{array}$ & $\begin{array}{l}\text { Seasonal Pasture } \\
\mathrm{w}^{[\mathrm{A}} \mathrm{AD} \mathrm{D}^{[\mathrm{b}]}\end{array}$ & $\begin{array}{l}\text { Annual } \\
\text { Pasture }\end{array}$ \\
\hline Lactating cows & 100 & 100 & 142 & 142 & 160 \\
Income from milk sales & 456,002 & 456,004 & 495,371 & 494,587 & 444,822 \\
Income from animal sales & 61,655 & 61,655 & 83,810 & 83,810 & 80,407 \\
Total production costs & 439,433 & 455,225 & 483,987 & 226,982 & 409,181 \\
Net income & 78,224 & 62,435 & 95,195 & 351,415 & 116,048 \\
Net income per cow & 782 & 624 & 670 & 2475 & 725 \\
\hline [a] Confinement with AD & & & & &
\end{tabular}

[a] Confinement with AD

[b] Seasonal pasture with imported manure, expanded land base for cash crop and AD 
